Jurnal Keperawatan Silampari

Volume 4, Nomor 1, Desember 2020

e-ISSN: 2581-1975

p-ISSN: 2597-7482

DOI: https://doi.org/10.31539/jks.v4i1.1408

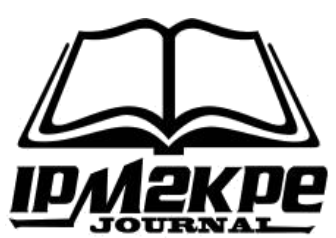

\title{
SUPERVISI KEPALA RUANGAN DALAM MENIGKATKAN BUDAYA KESELAMATAN PASIEN
}

\author{
Siti Fatonah ${ }^{1}$, Tito Yustiawan ${ }^{2}$ \\ Universitas Airlangga ${ }^{1,2}$ \\ siti.fatonah-2018@fkm.unair.ac.id ${ }^{1}$
}

\begin{abstract}
ABSTRAK
Penelitian bertujuan untuk mengetahui korelasi antara supervisi kepala ruangan dengan budaya keselamatan pasien di Instalasi Rawat Inap RSUD Nganjuk. Metode penelitian ini adalah penelitian kuantitatif analitik dengan desain studi cross sectional. Hasil penelitian menunjukkan bahwa kebanyakan responden terdiri dari perempuan $(74.4 \%)$ dengan usia antara 26 - 35 tahun $(52,6 \%)$ yang memiliki pendidikan D3/ sederajat $(71,8 \%)$. Hasil analisis bivariat menunjukkan bahwa nilai $\mathrm{p}$ sebesar $0,000<0,05$. Simpulan, terdapat hubungan yang signifikan antara supervisi kepala ruangan dengan budaya keselamatan pasien di Instalasi Rawat Inap RSUD Nganjuk.
\end{abstract}

Kata Kunci : Budaya Keselamatan Pasien, Rumah Sakit, Supervisi

\section{ABSTRACT}

This study aims to determine the correlation between the supervision of the head of the room with the culture of patient safety in the Nganjuk Hospital inpatient installation. This research method is a quantitative analytic study with a cross-sectional study design. The results showed that most respondents consisted of women (74.4\%) aged between $26-35$ years $(52.6 \%)$ who had a D3 / equivalent education (71.8\%). The results of the bivariate analysis showed that the p-value was $0.000<0.05$. In conclusion, there is a significant relationship between the supervision of the head of the room with the culture of patient safety in the Inpatient Installation of Nganjuk Hospital.

Keywords: Patient Safety Culture, Hospital, Supervision

\section{PENDAHULUAN}

Peraturan Menteri Kesehatan Nomor 11 Tahun 2017 tentang Keselamatan Pasien merumuskan 7 langkah menuju keselamatan pasien, salah satunya adalah dengan membangun kesadaran akan nilai keselamatan pasien. Pembangunan kesadaran terhadap nilai keselamatan pasien dapat diupayakan dengan membangun budaya keselamatan pasien yang efektif dan efisien. Terdapat 4 pilar utama dalam strategi membangum keselamatan pasien, salah satunya adalah dengan membangun budaya keselamatan pasien dengan memprioritaskan mutu dan keselamaatan pasien dalam visi dan penguatan positif bukan dengan menyalahkan dan hukuman (National Institute for Health Research, 2018; Kementerian Kesehatan Republik Indonesia, 2017).

Kesalahan pelayanan keperawatan merupakan keluaran yang disebabkan karena faktor lingkungan kerja dan budaya keselamatan pasien (Kim et al., 2018). Budaya keselamatan pasien sangat penting bagi fasilitas pelayanan kesehatan termasuk rumah sakit dan memerlukan keterlibatan semua pihak baik pimpinan, manajemen, staf yang terlibat, serta stakeholder rumah sakit.

AHRQ (2016) menyebutkan bahwa budaya keselamatan pasien merupakan produk dari nilai-nilai individu dan kelompok, sikap, persepsi, kompetensi, dan pola perilaku yang menentukan komitmen terhadap manajemen kesehatan dan keselamatan dari organisasi. Penerapan budaya keselamatan yang baik akan meningkatkan kesadaran provider pelayanan kesehatan mengenai pentingnya pelayanan yang aman serta pelaporan 
keselamatan pasien. Budaya keselamatan pasien dapat mendeteksi kesalahan yang akan terjadi atau yang telah terjadi sehingga dapat meningkatkan kesadaran pencegahan dan pelaporan. Penerapan budaya keselamatan pasien dapat ditingkatkan melalui kegiatan supervisi (Surahmat et al., 2019).

Kepala ruangan merupakan salah satu staf dalam manajemen yang menjadi penengah antara manajemen tingkat menengah dan staf pelaksana dalam rumah sakit. Kepala ruangan sebagai manajer lini pertama memiliki peran yang kritis dalam mendukung budaya keselamatan pasien dengan kepemipinan yang efektif dalam menciptakan lingkungan yang positif bagi keselamatan pasien salah satunya melalui supervisi (Pratiwi, 2019).

Supervisi merupakan hal penting yang digunakan untuk memastikan pelayanan yang diberikan telah sesuai dan memenuhi mutu pelayanan. Supervisi pelayanan keperawatan merupakan interaksi dan komunikasi professional antara supervisor keperawatan dan perawat pelaksana yakni dalam komunikasi tersebut perawat pelaksana menerima bimbingan, dukungan, bantuan, dan dipercaya, sehingga perawat pelaksana dapat memberikan asuhan yang aman kepada pasien, karena kegiatan supervisi semacam ini merupakan dorongan bimbingan dan kesempatan bagi pertumbuhan dan perkembangan keahlian serta kecakapan para perawat (Pratiwi, 2019).

RSUD Nganjuk merupakan rumah sakit tipe B non pendidikan yang merupakan rumah sakit yang menjadi pusat rujukan kesehatan di daerah Nganjuk. Pada tahun 2018, diketahui terdapat peningkatan insiden KTC (Kejadian Tidak Cedera) dan KTD (Kejadian Tidak Diinginkan). Insiden KTC terjadi peningkatan sebesar 3,47\% dari 14 kasus pada tahun 2017 menjadi 20 kasus pada tahun 2018 dan Insiden KTD terjadi kenaikan sebesar 11,56\% dari 20 kasus pada tahun 2017 menjadi 40 kasus dari tahun 2018. Hasil wawancara diketahui penerapan budaya keselamatan pasien belum dilaksanakan dengan maksimal karena masih termasuk baru digencarkan pada Agustus tahun 2018.

Pengukuran budaya keselamatan pasien di RSUD Nganjuk berdasarkan unit kerja, diketahui bahwa Instalasi Rawat Inap memiliki nilai budaya keselamatan pasien yang paling rendah $(56,25 \%)$ dari 27 unit lainnya. Oleh karena itu, pelaksanaan budaya keselamatan pasien di RSUD Nganjuk terutama di Instalasi Rawat Inap perlu dievaluasi untuk meingkatkankan penerapannya dan mengurangi insiden keselamatan pasien.

Penelitian sebelumnya mengenai hubungan supervisi dengan budaya keselamatan pasien yang dikemukakan oleh Wati et al., (2019) dilakukan pada RSUD Sanjiwani Gianyar dengan 94 responden terdapat hubungan yang signifikan antara supervisi keperawatan dengan pelaksanaan budaya keselamatan pasien. Sejalan dengan penelitian Agustina et al., (2018) yang dilakukan pada 81 perawat mendapatkan hasil bahwa terdapat hubungan yang signifikan antara supervisi keperawatan dengan pelaksanaan budaya keselamatan pasien.

Penelitian sebelumnya terdiri dari beberapa metode yang berbeda, namun pada ini supervisi dan budaya keselamatan pasien diukur dengan menggunakan instrument pengukuran yang jelas yaitu kuesioner yang mengacu pada MCSS (Manchester Clinical Supervision Scale) dan AHRQ (The Agency for Health Care Research and Quality), selain itu supervisi dan budaya keselamatan pasien di RSUD Nganjuk masih tergolong baru dan belum pernah dilakukan analisis serta pegukuran sebelumnya, sehingga penelitian ini diharapkan dapat menjadi dasar analisis dan evaluasi terkait budaya keselamatan pasien dan pelaksanaan supervisi di RSUD Nganjuk.

\section{METODE PENELITIAN}

Penelitian ini merupakan penelitian kuantitatif analitik dengan desain studi cross sectional. Berdasarkan pendekatannya, penelitian ini termasuk observasional karena peneliti tidak memberikan intervensi terhadap responden.

Data dikumpulkan selama 2 minggu dari tanggal 4 sampai dengan 18 Februari 2019 di Instalasi Rawat Inap RSUD Nganjuk. Data diperoleh dengan panduan kuesioner yang mengacu pada AHRQ (The Agency for Health Care Research and Quality) dan kuesioner dari Manchester Clinical Supervision Scale yang telah dimodifikasi. 
Budaya keselamatan pasien diukur dengan menggunakan panduan kuesioner dari AHRQ yang terdiri dari 12 dimensi, yaitu harapan dan tindakan manajer dalam mempromosikan patient safety, perbaikan organisasi yang berkelanjutan, kerja sama dalam unit, keterbukaan informasi, umpan balik dan komunikasi terhadap kesalahan, respon tidak menyalahkan, staffing, dukungan manajemen terhadap patient safety, kerja sama antar unit, handsoff dan transisi, persepsi staf mengenai patient safety, serta frekuensi pelaporan kejadian.

Supervisi kepala ruangan diukur dengan menggunakan kuesioner yang telah dimodifikasi dan mengacu pada Manchester Clinical Supervision Scale. Kuesioner ini terdiri dari 41 pertanyaan yang terbagi menjadi 3 faktor, yaitu normatif, formatif, dan restoratif.

Sampel berjumlah 156 perawat yang dipilih dengan menggunakan metode simple random sampling. Data dianalisis secara univariat untuk mendeskripsikan mengetahui distribusi karakteristik, dimensi budaya keselamatan pasien, dan faktor supervisi. Data juga dianalisis secara bivariat dengan menggunakan Kendall's tau-b test untuk mengetahui hubungan antar variabel (budaya keselamatan dengan supervisi kepala ruangan).

\section{HASIL PENELITIAN Karakteristik Responden}

Tabel. 1

Karakteristik Responden

\begin{tabular}{|c|c|c|}
\hline Variabel & Jumlah (n) & Persentase (\%) \\
\hline \multicolumn{3}{|l|}{ Jenis Kelamin } \\
\hline Laki-laki & 40 & 25.6 \\
\hline Perempuan & 116 & 74.4 \\
\hline \multicolumn{3}{|l|}{ Tingkat pendidikan } \\
\hline SMA/Sederajat & 3 & 1.9 \\
\hline D3/ sederajat & 112 & 71.8 \\
\hline $\mathrm{S} 1 /$ sederajat & 41 & 26.3 \\
\hline \multicolumn{3}{|l|}{ Usia } \\
\hline $16-25$ & 1 & 0.6 \\
\hline $26-35$ & 82 & 52.6 \\
\hline $36-45$ & 58 & 37.2 \\
\hline $46-55$ & 13 & 8.3 \\
\hline$>56$ & 2 & 1.3 \\
\hline Total & 156 & 100 \\
\hline
\end{tabular}

Berdasarkan tabel 1 mayoritas responden berjenis kelamin perempuan yaitu sebanyak $119(74,4 \%)$ responden. Mayoritas responden memiliki tingkat pendidikan terakhir D3/ sederajat sebanyak $112(71,8 \%)$ responden. Mayoritas responden masih berusia produktif, yaitu berusia antara $26-35$ tahun sebanyak $82(52,6 \%)$ responden.

\section{Supervisi Kepala Ruangan}

Tabel. 2

Supervisi Kepala Ruangan

\begin{tabular}{|c|c|c|}
\hline Supervisi & Frequency & Percent \\
\hline Kurang & 7 & 4.5 \\
\hline Sedang & 146 & 93.6 \\
\hline Baik & 3 & 1.9 \\
\hline Total & 156 & 100.0 \\
\hline
\end{tabular}

Berdasarkan tabel 2 supervisi kepala ruangan di Instalasi Rawat inap mayoritas masih termasukdalam kategori sedang yaitu sebanyak $146(93,6 \%)$ responden. 
Tabel. 3

Distribusi Supervisi Kepala Ruangan Berdasarkan Dimensi

\begin{tabular}{|c|c|c|}
\hline Supervisi & Frequency & Percent \\
\hline \multicolumn{3}{|l|}{ Normatif } \\
\hline Kurang & 121 & 13.5 \\
\hline Sedang & 131 & 84.0 \\
\hline Baik & 4 & 2.6 \\
\hline \multicolumn{3}{|l|}{ Formatif } \\
\hline Kurang & 8 & 5.1 \\
\hline Sedang & 146 & 93.6 \\
\hline Baik & 2 & 1.3 \\
\hline \multicolumn{3}{|l|}{ Restoratif } \\
\hline Kurang & 17 & 10.9 \\
\hline Sedang & 131 & 84.0 \\
\hline Baik & 8 & 5.1 \\
\hline Total & 156 & 100.0 \\
\hline
\end{tabular}

Berdasarkan tabel 3 supervisi kepala ruangan secara normatif, formatif dan restoratif termasuk dalam supervisi sedang dengan persentase berturut-turut yaitu normatif sebesar $84,0 \%$; formatif sebesar $93,6 \%$; dan restoratif sebesar $84,0 \%$.

\section{Budaya Keselamatan Pasien}

Tabel. 4

Distribusi Budaya Keselamatan Pasien

\begin{tabular}{llll}
\hline \multicolumn{1}{c}{ Budaya Keselamatan Pasien } & & Frequensi (n) & Percentase (\%) \\
\hline Lemah & 4 & 2.6 \\
Sedang & 148 & 94.9 \\
Kuat & 4 & 2.6 \\
\hline Total & 156 & 100.0 \\
\hline
\end{tabular}

Berdasarkan tabel 4 menunjukkan bahwa mayoritas penerapan budaya keselamatan pasien termasuk penerapan sedang dengan persentase sebesar 94,9\%.

Tabel. 5

Distribusi Budaya Keselamatan Pasien Setiap Dimensi

\begin{tabular}{|c|c|c|c|c|c|c|c|}
\hline \multirow{3}{*}{ No } & \multirow{3}{*}{ Dimensi } & \multicolumn{6}{|c|}{ Kategori } \\
\hline & & \multicolumn{2}{|c|}{ Lemah } & \multicolumn{2}{|c|}{ Sedang } & \multicolumn{2}{|c|}{ Kuat } \\
\hline & & $\sum$ & $\%$ & $\sum$ & $\%$ & $\sum$ & $\%$ \\
\hline 1 & $\begin{array}{l}\text { Harapan dan tindakan manajer dalam } \\
\text { mempromosikan patient Safety }\end{array}$ & 145 & 92.9 & 11 & 7.1 & 0 & 0 \\
\hline 2 & Perbaikan organisasi yang berkelanjutan & 123 & 78.8 & 33 & 21.2 & 0 & 0 \\
\hline 3 & Kerja sama dalam unit & 14 & 9 & 112 & 71.8 & 30 & 19.2 \\
\hline 4 & Keterbukaan informasi & 53 & 34 & 93 & 59.6 & 10 & 6.4 \\
\hline 5 & Umpan balik dan komunikasi terhadap kesalahan & 34 & 21.8 & 99 & 63.5 & 23 & 14.7 \\
\hline 6 & Respon respon tidak menyalahkan & 99 & 63.5 & 51 & 32.7 & 6 & 3.8 \\
\hline 7 & Staffing & 49 & 31.4 & 101 & 64.7 & 6 & 3.8 \\
\hline 8 & Dukungan manajemen terhadap patient safety & 25 & 16 & 97 & 62.2 & 34 & 21.8 \\
\hline 9 & Kerja sama antar unit & 17 & 10.9 & 100 & 64.1 & 39 & 25 \\
\hline 10 & Handsoff dan transisi & 16 & 10.3 & 108 & 69.2 & 32 & 20.5 \\
\hline 11 & Persepsi staf mengenai patient safety & 48 & 30.8 & 102 & 65.4 & 6 & 3.8 \\
\hline 12 & Frekuensi pelaporan kejadian & 28 & 17.9 & 97 & 62.2 & 31 & 19.9 \\
\hline & Total & 156 & 100 & 156 & 100 & 156 & 100 \\
\hline
\end{tabular}


Berdasarkan tabel 5 menunjukkan distribusi budaya keselamatan pasien di Instalasi Rawat Inap RSUD Nganjuk tahun 2019 berdasarkan pada setiap dimensi. Terdapat 9 dari 12 dimensi yang mayoritas perawatnya memiliki budaya keselamatan pasien sedang, yaitu dimensi kerja sama dalam unit, keterbukaan informasi, umpan balik dan komunikasi terhadap kesalahan, staffing, dukungan manajemen terhadap patient safety, kerja sama antar unit, handsoff dan transisi, persepsi staf mengenai patient safety, dan frekuensi pelaporan kejadian.

Dimensi yang mayoritas perawatnya masih memiliki budaya keselamatan pasien lemah terdapat 3 dimensi, yaitu harapan dan tindakan manajer dalam mempromosikan patient safety, perbaikan organisasi yang berkelanjutan, dan respon tidak menyalahkan. Meskipun mayoritas dimensi telah memiliki budaya keselamatan pasien sedang, namun tidak terdapat dimensi yang mayoritas perawatnya telah termasuk dalam kategori budaya keselamatan kuat.

\section{Hubungan Supervisi Kepala Ruangan dengan Budaya Keselamatan Pasien}

\begin{tabular}{rcc} 
& \multicolumn{2}{c}{$\begin{array}{c}\text { Tabel. 6 } \\
\text { Hubungan Supervisi Kepala Ruangan } \\
\text { dengan Budaya Keselamatan Pasien }\end{array}$} \\
\hline & Variabel & Budaya keselamatan pasien \\
\hline \multirow{2}{*}{ Supervisi Kepala Ruangan } & Correlation Coefficient & $.559^{* *}$ \\
\cline { 2 - 3 } & Sig. (2-tailed) & .000 \\
\hline
\end{tabular}

Berdasarkan tabel 6 menunjukkan hasil analisis bivariate menunjukkan signifikansi sebesar $0,000<0,05$. Koefisien korelasi antara X1 dan X2 sebesar 0,559 menunjukkan bahwa korelasi antara supervisi kepala ruangan dan budaya keselamatan pasien termasuk cukup kuat. Hasil analisis statistik tersebut memiliki arti bahwa supervisi kepala ruangan (X1) dan budaya keselamatan pasien (X2) memiliki korelasi yang signifikan dan cukup kuat. Semakin baik supervisi yang dilakukan oleh kepala ruangan akan berdampak pada budaya keselamatan pasien yang semakin kuat pada perawat di Inslatasi Rawat Jalan RSUD Nganjuk.

\section{PEMBAHASAN}

\section{Supervisi Kepala Ruangan}

Supervisi biasanya didefinisikan berdasarkan 3 fungsinya berdasarkan Proctor Functional Interactive model yang meliputi fungsi yaitu normative (managerial), formatif (educational), dan restorative (supportive). Supervisi kepala ruangan RSUD Nganjuk termasuk dalam kategori sedang. Namun berdasarkan hasil wawancara, pelaksanaan supervisi masih belum terjadwal dan terprogam dengan baik. Sejalan dengan penelitian Oxyandi et al., (2019) yang menemukan bahwa kegiatan supervisi di ruangan belum dapat berjalan secara optimal, dikarenakan berbagai faktor yang mempengaruhinya salah satunya dikarenakan kegiatan supervisi keperawatan dilakukan secara situasional dan belum terjadwal.

Selanjutnya Oxyandi et al., (2019) menjelaskan bahwa evaluasi kegiatan prioritas masalah poin belum optimalnya penerapan supervisi keperawatan di ruangan Madinah antara lain hasil diseminasi ilmu (peserta menjawab dengan benar dari 60 peserta); Pretest $50 \%$ dan meningkat pada Posttest $85 \%$, adanya draft kebijakan tentang supervisi keperawatan, adanya draft Standar Prosedur Operasional (SPO) tentang supervisi keperawatan, adanya format supervisi keperawatan di ruangan madinah, lembar absensi kegiatan sosialisasi format supervisi keperawatan, dan adanya dokumentasi hasil supervisi yang dilakukan oleh karu Madinah.

Kepala ruang mempunyai tanggung jawab dalam organisasi dan menentukan pencapaian tujuan organisasi, dalam hal ini melakukan pengawasan untuk meningkatkan keselamatan pasien yang dilakukan perawat dan mencegah terjadinya insiden keselamatan 
pasien (Yusuf, 2017). Kepala ruangan perlu mengembangkan kepemimpinan dalam mendukung peran perawat dalam gerakan keselamatan pasien dengan mengidentifikasi kebutuhan dalam pelaksanaan sasaran keselamatan pasien dan lebih intensif dalam pengawasan secara berkala (Pambudi et al., 2018).

Normatif (managerial) merupakan merupakan fungsi manajerial untuk perbaikan, peningkatan, dan pengendalian kualitas praktek professional pelayanan keperawatan. Supervisi kepala ruangan di Instalasi Rawat Inap RSUD Nganjuk sebagian besar perawat memberikan penilaian yang termasuk sedang $(84.0 \%)$. Penilaian ini menunjukkan bahwa perawat pelaksana masih belum merasakan adanya interaksi yang baik dalam supervisi pelayanan keperawatan dalam usaha peningkatan profesionalisme perawat. Interaksi yang baik antara supervisor dan perawat terkait profesionalisme perawat merupakan hal penting yang berkaitan langsung dengan pemberian pelayanan yang aman. Supervisi pada domain normative dianggap cukup pada komponen ini mengindikasikan bahwa perawat pelaksana cukup merasakan bahwa supervisi keperawatan tidak hanya sebatas pengawasan atas pekerjaan saja tapi juga cukup mampu untuk menciptakan lingkungan kerja yang kondusif, membuat suatu perencanaan, mengidentifikasi kebutuhan dan permasalahan yang dibutuhkan untuk memberikan dukungan kerja yang lebih lanjut, menciptakan keselamatan pasien, mempertahankan standar yang ada, dan memberikan kepercayaan kepada perawat pelaksana sehingga hal tersebut dapat meningkatkan profesionalisme dan menciptakan kualitas pelayanan keperawatan yang bermutu (Wati et al., 2019).

Fungsi formatif merupakan proses edukatif untuk mengembangkan pengetahuan, keterampilan dan sikap keperawatan. Domain formatif dari supervisi kepala ruangan merupakan domain yang paling banyak mendapatkan penilaian sedang dari responden (93.6\%). Pengaruh kognitif terkait pemberian bimbingan dalam supervisi dapat berpa pengetahuan perawat. Pengetahuan, keterampilan, dan sikap berperan penting dalam penerapan keselamatan pasien karena hal tersebut yang menjadi dasar perawat dalam memberikan pelayanan. Fungsi formatif termausk sedang atau cukup mengindikasikan Supervisor keperawatan cukup mampu melaksanakan komponen edukatif supervisi keperawatan dengan salah satu cara seperti memberikan orientasi mengenai programprogram peningkatan mutu rumah sakit tidak hanya kepada perawat pelaksana yang baru bekerja tetapi juga kepada seluruh perawat pelaksana (Wati et al., 2019).

Supervisi merupakan bagian dari fungsi directing (pengarahan) dalam fungsi manajemen yang berperan untuk mempertahankan agar segala kegiatan yang telah diprogramkan dapat dilaksanakan dengan benar dan lancar (Oxyandi et al., 2019). Supervisi merupakan aktivitas yang harus rutin dilakukan guna mencapai implementasi sasaran keselamatan pasien yang lebih oprimal sehingga keselamatan pasien akan menadi prioritas pada setiap aktivitas dan penerapannya menjadi budaya yang harus dilakukan oleh seluruh perawat tanpa terkecuali (Surahmat et al., 2019). Komunikasi antara supervisor (kepala ruangan) dengan perawat yang baik dapat memberikan dorongan bimbingan dan keberanian pada perawat untuk meneliti masalah-masalah yang ada dalam tim, keterbukaan membahas isu atau topik yang berkaitan dengan pekerjaannya. Hubungan antara perawat yang disupervisi dengan supervisor dikarakteristikkan sebagai peningkatan evaluasi diri, keberanian, keterbukaan, menolong dan saling memahami antar anggota tim (Irawan et al., 2017). Dengan demikian, supervisi yang baik akan membentuk perilaku perawat yang membudaya terhadap keselamatan pasien.

Supervisi merupakan komitmen kepala ruangan dalam upaya penerapan budaya keselamatan pasien sehingga dalam pelaksanaannya berkaitan dengan kepemimpinan kepala ruangan. Kepemimpinan efektif kepala ruangan merupakan salah satu faktor yang berperan dalam budaya keselamatan pasien dimana pengetahuan yang didapatkan dari pendidikan dan pelatihan merupakan faktor yang dapat meningkatkan kemampuan untuk melakukan perubahan (Pratiwi, 2019). Oleh karena itu, pendidikan dan pelatihan menegnai supervisi juga dapat digencarkan rumah sakit sebagai upaya dalam meningkatkan kegiatan supervisi yang efektif. 


\section{Budaya Keselamatan Pasien}

Budaya keselamatan pasien (patient safety culture) merupakan nilai, persepsi, keyakinan, sikap, kompetensi dan pola perilaku dari setiap individu yang dihasilkan oleh individual dan kelompok yang ditetapkan berdasarkan komitmen dan gaya dari manajemen organisasi kesehatan yang ada di rumah sakit untuk menjamin keselamatan pasien selama perawatan (Wati et al., 2018). Budaya keselamatan pasien merupakan pondasi utama dalam menuju keselamatan pasien. Peraturan Menteri Kesehatan Nomor 11 Tahun 2017 tentang Keselamatan Pasien merumuskan 7 langkah menuju keselamatan pasien, langkah pertama yang harus dilakukan adalah dengan membangun kesadaran akan nilai keselamatan pasien melalui pembangunan budaya keselamatan (Pratiwi, 2019).

Survey budaya keselamatan pasien dapat digunakan sebagai salahsatu metode dalam mengevaluasi dan memonitoring pelaksanaan budaya keselamatan pasien di institusi pelayanan kesehatan seperti rumah sakit. Budaya keselamatan pasien di Instalasi Rawat Inap RSUD Nganjuk termasuk dalam kategori sedang. Penerapan budaya keselamatan pasien memerlukan komitmen dari berbagai pihak, baik perawat, manajer, direktur, stakeholder, hingga pasien itu sendiri. Dimensi budaya keselamatan pasien yang mayoritas perawatnya masih rendah pada RSUD Nganjuk terdapat 3 dimensi, yang meliputi harapan dan tindakan manajer mengenai budaya keselamatan pasien, perbaikan organisasi berkelanjutan, dan respon tidak menyalahkan.

Harapan dan tindakan manajer mengenai budaya keselamatan pasien di RSUD Nganjuk masih tergolong rendah karena mayoritas perawat $(92,2 \%)$ memiliki persepsi bahwa manajer belum berorientasi dalam penerapan budaya keselamatan pasien. Harapan dan tindakan manajer dalam menerapkan budaya keselamatan pasien merupakan faktor penting dimana hal tersebut menunjukkan komitmen dan tindakan manajer terhadap upaya pengurangan insiden keselamatan pasien di rumah sakit. Manajemen perlu melakukan intervensi lebih lanjut terhadap manajer terkait penerapan budaya keselamatan pasien.

Perbaikan organisasi yang berkelanjutan di RSUD Nganjuk pada mayoritas perawat $(78,8 \%)$ termasuk dalam kategori rendah. Hal ini dikarenakan pengukuran budaya keselamatan pasien di RSUD Nganjuk masih tergolong baru, sehingga tindaklanjut terhadap insiden keselamatan pasien di RSUD Nganjuk masih perlu ditingkatkan. Laporan terhadap insiden keselamatan pasien juga harus mendapatkan umpan balik untuk memastikan bahwa insiden keselamatan pasien dijadikan sebagai bahan evaluasi dan perbaikan berkelanjutan.

Respon tidak menyalahkan merupakan faktor penting dalam penerapan budaya keselamatan pasien. Budaya keselamatan pasien yang kondusif akan menimbulkan rasa percaya diri pada perawat dalam memberikan pelayanan yang aman. Respon tidak menyalahkan pada perawat apabila terjadi insiden keselamatan dapat meningkatkan keterbukaan perawat dalam melaporkan insiden keselamatan pasien. Tanpa perubahan budaya, perspektif, dan sikap terhadap insiden dan penyebabnya, perawat tidak mungkin melaporkan insiden dan melakukan tindakan perubahan untuk mencegah insiden. Pelaporan insiden keselamatan pasien merupakan hal penting untuk evaluasi dan memastikan bahwa intervensi atau tindakan perbaikan yang dilakukan telah tepat dan efektif.

Keselamatan pasien adalah sebuah transformasi budaya, dimana budaya yang diharapkan adalah budaya keselamatan, budaya tidak menyalahkan, budaya lapor dan budaya belajar (Hasmi \& Thabrany, 2019). Budaya keselamatan pasien dapat memberikan perbahan positif terhadap perkembangan organisasi. Meningkatkan budaya keselamatan akan membantu mengurangi biaya pada pasien yang menderita peningkatan rasa sakit, cacat, trauma fisik dan psikologis, rasa bersalah, malu, kehilangan kepercayaan diri dan moral; meningkatkan target nasional, serta mengurangi persyaratan untuk perawatan tambahan dan tempat tidur tambahan.

\section{Korelasi Supervisi Kepala Ruangan dengan Budaya Keselamatan Pasien}

Supervisi kepala ruangan dan budaya keselamatan pasien di RSUD Nganjuk menunjukkan terdapat hubungan yang signifikan $(\mathrm{p}=0,000)$ dan kuat (coefficient correlation $=0,559)$. Penerapan budaya keselamatan pasien bagi perawat pelaksana memerlukan peran penting 
supervisi untuk mewujudkan keselamaan pasien dalam pelayanan keperawatan di rumah sakit (Irawan et al., 2017).

Hasil penelitian Desi et al., (2017) mengatakan supervisi keperawatan merupakan suatu proses kegiatan pemberian dukungan sumber-sumber yang dibutuhkan perawat dalam rangka menyelesaikan tugas untuk mencapai tujuan yang telah ditetapkan. Jadi supervisi keperawatan adalah sebuah aktivitas pemantauan yang dilakukan oleh seseorang terhadap pelaksanaan tugas yang dilakukan bawahan dan memberikan bantuan apabila diperlukan.

Penelitian ini sesuai dengan penelitian yang dilakukan oleh Wati et al., (2019) yang menemukan bahwa ada hubungan signifikan dan berpola positif antara supervisi keperawatan dengan pelaksanaan budaya safety. Penelitian tersebut menyebutkan bahwa terdapat hubungan yang signifikan dengan nilai kekuatan korelasi sedang $(\mathrm{r}=0,478)$ yang artinya semakin baik supervisi maka semakain baik pelaksanaan budaya safety oleh perawat pelasakana di Ruag Rawat Inap RSUD Sanjiwani Gianyar.

Penelitian Agustina et al., (2018) juga menemukan bahwa terdapat hubungan yang signifikan dan kuat antara supervisi dan budaya keselamatan pasien dengan nilai signifikansi sebesar 0,000 dan koefisien korelasi sebesar 0,604. Supervisi kepala ruangan yang baik dan efektif akan membuat budaya keselamatan pasien pada perawat menjadi maksimal karena supervisi dapat mempengaruhi budaya keselamatan pasien. Hubungan yang baik dan terbuka antara supervisor keperawatan dan perawat pelaksana akan meningkatkan pencapaian standar pelayanan, sehingga sangat memberi manfaat yang potensial baik bagi supervisor keperawatan, perawat, dan pasien.

Penerapan budaya keselamatan pasien sangat penting dilakukan oleh institusi pelayanan kesehatan seperti rumah sakit. Penerapan budaya keselamatan pasien akan mendeteksi kesalahan yang akan terjadi atau jika kesalahan telah terjadi budaya keselamatan pasien akan meningkatkan kesadaran untuk mencegah dan melaporkan jika ada kesalahan (Pratiwi, 2019). Budaya keselamatan yang baik akan membentuk persepsi dan kepercayaan diri pada perawat dalam memberikan pelayanan yang aman dan sesuai dengan standar yang telah diterapkan sehingga secara bertahap akan mengurangi insiden keselamatan pasien.

Inti dari budaya keselamatan pasien adalah keyakinan karyawan tentang pentingnya keselamatan, yang ditunjukkan melalui sikap, norma-norma yang berlaku dan perilaku termasuk nilai-nilai yang menjadi asumsi dasar tentang bagaimana bertindak (Hasmi \& Thabrany, 2019). Budaya keselamatan pasien bermanfaat menyadari kesalahan dan pembelajaran terhadap kesalahan sehingga dapat membangun organisasi melalui kebijakan keselamatan pasien.

Supervisi kepala ruangan merupakan salah satu bentuk monitoring terhadap pelayanan yang diberikan oleh perawat. Supervisi tidak dapat diartikan sebagai pemeriksaan atau pencarian kesalahan, namun pengawasan partisipatif lebih mendahulukan penghargaan terhadap pencapaian positif, memberikan jalan keluar terhadap masalah, dan menyempurnakan proses pemberian pelayanan (Agustina et al., 2018). Supervisi dapat dijadikan sebagai proses evaluasi untuk perbaikan berkelanjutan bagi rumah sakit dengan mengawasi baik secara langsung maupun tidak langsung terhadap proses pemberian pelayanan yang aman.

Supervisi klinik tidak dapat diartikan sebagai pemeriksaan atau mencari kesalahan, tetapi lebih kepada pengawasan partisipatif, mendahulukan penghargaan terhadap pencapaian hasil positif, memberikan jalan keluar terhadap hal yang masih belum dapat dilakukan, dan biasanya supervisi dilakukan dengan cara supervisi langsung dan tidak langsung (Agustina et al., 2018).

Supervisi yang baik pada staf pelaksana di rumah sakit mengindikasikan adanya hubungan kerja yang baik antara supervisor (kepala ruangan) dengan perawat pelaksana. Komunikasi merupakan faktor kunci dalam membangun hubungan yang baik antara kepala ruangan dan perawat.

Supervisi dapat dilakukan dengan menerapkan kepemimpinan yang melayani staf untuk menciptakan rasa saling menghargai dan meningkatkan hubungan yang positif antara kepala ruangan dengan perawat. Peran supervisi sangat penting dalam membangun budaya 
keselamatan pasien, sehingga diharapkan kompetensi supervisi dapat ditingkatkan melalui pelatihan dan dapat menerapkan aktivitas supervisi melalui program sosialisasi, mentoring, konseling, serta penguatan peran komite kesalamatan pasien dalam melakukan survei budaya keselamatan (Pratiwi, 2019).

Mendengarkan merupakan keterampilan penting yang harus dimiliki oleh pemimpin sehingga pemimpin dapat mengidentifikasi dan mengklarifikasi informasi lebih banyak untuk evaluasi. Empati pemimpin diperlukan untuk memberikan semangat dan pemahaman pada staf sehingga dapat memotivasinya untuk meningkatkan pelayanan yang diberikan. Seorang pemimpin juga harus memiliki perilaku healing, dimana pemimpin membantu staf dalam menghadapi masalah-masalah terkait pekerjaan.

Karakteristik pemimpin yaitu melakukan persuasi kepada staf untuk menciptakan hubungan yang saling percaya antara staf dan pemimpin. Pemimpin harus memiliki kesadaran dalam memahami isu situasi dengan melibatkan etika, nilai, dan mengintegrasikannya untuk pengambilan keputusan terkait perencanaan masa depan sehingga sesuai dengan konsep perencanaan yang dimilikinya.

Komitmen pada pertumbuhan staf terkait personal, professional, dan sprititual juga merupakan karakteristik pemimpin. Penatalayanan yang baik berperan penting dalam menciptakan good society pada organisasi sehingga hal tersebut dapat membangun komunitas yang ada dalam organisasi untuk berkembang.

Kesalahan pelayanan keperawatan dapat diatasi dengan mengimplementasikan lingkungan kerja dan budaya keselamatan yang positif (Kim et al., 2018). Supervisi yang baik akan menimbulkan hubungan dan iklim kerja yang baik antara kepala ruangan dengan perawat sehingga dapat membentuk lingkungan kerja yang positif pula. Penerapan budaya negatif menuju penerapan budaya keselamatan mengindikasikan terjadi perubahan dalam sistem suatu organisasi maupun perilaku dari anggota organisasi (Pratiwi, 2019).

Pembentukan budaya keselamatan pasien yang baik bukan merupakan hal yang mudah dan cepat diterapkan karena budaya merupakan nilai-nilai bersama, asumsi dan pembelajaran terhadap upaya bersama dalam memberikan pelayanan pasien yang lebih aman dan mencegah insiden keselamatan pasien. Tindakan asuhan keperawatan bertujuan untuk meningkatkan keselamatan pasien keamanan dengan cara menransformasikan pelayanan yang mengutamakan keselamatan oleh staf perawat menjadi budaya organisasi, dimana dalam pelaksanannya meterlibatkan dukungan manajemen baik pada tahap perencanaan, implementasi, hingga evaluasi (Costa et al., 2018).

Budaya keselamatan pasien dapat ditingkatkan dengan melakukan supervisi kepala ruangan yang baik untuk mendukung pelaksanaan pelayanan keperawatan yang aman. Hubungan yang signifikan dan kuat antara supervisi kepala ruangan dan budaya keselamatan pasien di Instalasi Rawat Inap memerlukan perhatian dan evaluasi berkelanjutan oleh RSUD Nganjuk.

\section{SIMPULAN}

Kararteristik responden yaitu mayoritas responden terdiri dari perempuan dengan usia antara 26-35 tahun yang memiliki pendidikan D3/sederajat. Supervisi kepala ruangan di Instalasi Rawat Inap RSUD Nganjuk tahun 2019 termasuk sedang. Mayoritas perawat dengan domain normatif, formatif, dan restorative yang masih dinilai sedang sehingga masih memerlukan peningkatan dan evaluasi. Budaya keselamatan pasien dinilai mayoritas perawat telah termasuk dalam kategori budaya sedang. Terdapat 3 dimensi yang mayoritas perawat masih memberikan penilaian termasuk dalam budaya lemah yaitu harapan dan tindakan manajer dalam mempromosikan patient Safety, perbaikan organisasi yang berkelanjutan, dan respon respon tidak menyalahkan.

Terdapat hubungan yang signifikan antara supervisi kepala ruangan dengan budaya keselamatan pasien di Instalasi Rawat Inap RSUD Nganjuk dengan hubungannya termasuk cukup kuat. Hal tersebut mengindikasikan bahwa supervisi kepala ruangan yang baik akan meningkat penerapan budaya keselamatan pasien di Instalasi Rawat Inap RSUD Nganjuk. Budaya keselamatan pasien perlu diringkatkan dan dievaluasi ulang oleh berbagai pihak dalam rumah sakit baik direktur, manajer, staf, meupun stakeholder. 


\section{SARAN}

Saran yang dapat diberikan adalah dengan memberikan pelatihan mengenai supervisi kepada kepala ruang, memberikan sosialisasi dan edukasi mengenai pentingnya keselamatan pasien, meningkatkan komitmen pemegang keputusan dan stakeholder terkait di RSUD Nganjuk untuk meningkatkan budaya keselamatan pasien, sala satunya dengan memasukkan budaya keselamatan pasien sebagai indicator mutu atau rencana strategis rumah sakit serta memberikan fasilitas sumber daya yang memadai untuk meningkatkan dan mengevaluasi pelaksanaan keselamatan pasien di RSUD Nganjuk.

\section{DAFTAR PUSTAKA}

Agustina, M. A., Istiningtyas, A., \& Harti, A. S. (2018). Hubungan antara Supervisi Klinik terhadap Budaya Keselamatan Pasien berdasarkan Persepsi Perawat di RSUD dr. Soehadi Prijonegoro Sragen. Artikel Jurnal Skripsi Keperawatan, 1-12. www.digilib.stikeskusumahusada.ac.id/download.php?id=2553

Costa, D. B., Ramos, D., Gabriel, C. S., \& Bernandes, A. (2018). Patient Safety Culture : Evaluation by Nursing Professional. Texto Contexto Enferm, 27(3), 1-9. https://doi.org/http://dx.doi.org/10.1590/0104-070720180002670016

Desi, H. D., Sumaryani, S., \& Rosa, M. E. (2017). Evaluasi Pelaksanaan Supervisi Keperawatan di Rumah Sakit Umum Daerah Panembahan Senopati Bantul. Jurnal Medicoeticolegal Dan Manajemen Rumah Sakit, 6(1), 47-54. https://doi.org/10.18196/jmmr.6126

Hasmi, Y., \& Thabrany, H. (2019). Faktor-faktor yang Berhubungan dengan Budaya Keselamatan Pasien di Rumah Sakit Karya Bhakto Pratiwi Bogor Tahun 2015. Administrasi Rumah Sakit, 4(2), 98-109. https://doi.org/http://dx.doi.org/10.7454/arsi.v4i2.2563

Irawan, A. G., Yulia, S., \& Muliyadi, M. (2017). Hubungan Supervisi dengan Penerapan Budaya Keselamatan Pasien Di Ruang Rawat Inap Rumah Rumah Sakit XX. Poltekes Kementerian Kesehatan Palembang, 5(1), 1-14. https://ejournal.stikesmp.ac.id/index.php/maskermedika/article/view/164

Kementerian Kesehatan Republik Indonesia. (2017). Peraturan Menteri Kesehatan RI No. 11 Tahun 2017 tentang Keselamatan Pasien. Berita Negara Republik Indonesia, 308, 1-48. http://www.albayan.ae

Kim, K. J., Yoo, M. S., \& Seo, E. J. (2018). Exploring the Influence of Nursing Work Environment and Patient Safety Culture on Missed Nursing Care in Korea. Asian Nursing Research, 12(2), 121-126. https://doi.org/10.1016/j.anr.2018.04.003

National Institute for Health Research. (2018). Patient Safety 2020: London: NIHR Imperial Patient Safety Translational Research Centre. https://www.who.int/teams/integrated-health-services/patient-safety

Oxyandi, M., Yanthi, Y., Murni, D., \& Maisa, E. A. (2019). Supervisi Keperawatan Optimalisasi Peran Kepala Ruangan Melalui Supervisi Keperawatan Berbasis House Trainning pada Kegiatan Identifikasi Resiko Jatuh dengan Metode Humpty Dumpty. Jurnal Pengabdian Harapan Ibu (JPHI), $\quad 1(2), \quad 29$. https://doi.org/10.30644/jphi.v1i2.232

Pambudi, Y. D. W., Sutriningsih, A., \& Yasin, D. D. F. (2018). Faktor-Faktor yang Mempengaruhi Perawat Dalam Penerapan 6 SKP (Sasaran Keselamatan Pasien) Pada Akreditasi JCI (Joint Commision International) di Ruang Rawat Inap Rumah Sakit Panti Waluya Malang. Nursing News, 3(1), 729-747. https://publikasi.unitri.ac.id/index.php/fikes/article/view/844/657

Pratiwi, I. (2019). Peran Supervisi Menuju Budaya Keselamatan Pasien. INA-Rxiv. https://doi.org/https://doi.org/10.31227/osf.io/z2e4h

Surahmat, R., Neherta, M., \& Nurariati, N. (2019). Hubungan Supervisi dengan Implementasi Sasaran Keselamatan Pasien di Rumah Sakit Muhammadiyah Palembang. Proceeding Seminar Nasional Keperawatan, 4(1), 173-178. http://conference.unsri.ac.id/index.php/SNK/article/view/1210 
Wati, N. N. M., Prihatiningsih, D., \& Haryani, N. N. P. (2019). Hubungan Supervisi Keperawatan dengan Pelaksanaan Budaya Safety. Adi Husada Nursing Journal, 4(2), 56. https://doi.org/10.37036/ahnj.v4i2.126

Yusuf, M. (2017). Penerapan Patient Safety Di Ruang Rawat Inap Rumah Sakit Umum Daerah Dr . Zainoel Abidin Patient Safety Implementation In Ward Of Dr . Zainoel Abidin General Hospital. Jurnal Ilmu Keperawatan, 5(1), 1-6. http://www.jurnal.unsyiah.ac.id/JIK/article/view/8766 